\title{
Evaluation of the Yields and the Dry Matter Content of Seven (7) Sweet Potato Varieties (Ipomoea Batatas (L), Lam., 1793) in the Bouake Region, Côte D'Ivoire
}

Kouame Nguessan $^{*}$, Dibi Konan Evrard Brice ${ }^{2}$, Essis Brice Sidoine ${ }^{2}$, Toure Nin Céline ${ }^{1}$, Ngbesso Mako François De $\mathrm{Paul}^{3}$

${ }^{1}$ University Jean Lorougnon GUEDE, Agricultural Production Improvement Laboratory, UFR Agroforestry, BP 150 Daloa, Côte d'Ivoire

${ }^{2}$ National Center for Agronomic Research (CNRA), Root and Tuber Crops Program (PRT), Food Crops Research Station (SRCV), 01 BP 633 Bouaké 01, Côte d'Ivoire

${ }^{3}$ National Center for Agronomic Research (CNRA), Vegetable and Proteagineous Crops Program (CMP), Food Crops Research Station (SRCV), 01 BP 633 Bouaké 01, Côte d'Ivoire

DOI: $10.36347 /$ sjavs.2020.v07i01.004

| Received: 20.01.2020 | Accepted: 27.01.2020 | Published: 30.01.2020

*Corresponding author: Kouame Nguessan

Abstract

Original Research Article

The sweet potato is cultivated in all regions of Côte d'Ivoire. It's consumed in various forms (vegetable, fried, boiled, foutou, etc.). However, many factors such as the gradual loss of traditional varieties limit the production of this crop. To cope with this problem, the country has introduced new high-performance varieties. The introduction of these varieties requires selection. It is within this framework that this study was carried out in order to assess the yields and the dry matter rate of seven (7) varieties of sweet potato (Ipomoea batatas (L), lam., 1793) in the region from Bouake, Côte d'Ivoire. The results obtained showed that the weight of the tubers, the number of tubers and the shape of the tuberous roots of the varieties Covington and CIP were the highest. These two varieties can therefore be recommended to farmers.

Keywords: Performances, New variety, Selection, Tubers.

Copyright @ 2020: This is an open-access article distributed under the terms of the Creative Commons Attribution license which permits unrestricted use, distribution, and reproduction in any medium for non-commercial use (NonCommercial, or CC-BY-NC) provided the original author and source are credited.

\section{INTRODUCTION}

Sweet potato is in the word the seventh (7th) major food crop after wheat, rice, corn, potato, barley and cassava [1]. It is the second (2nd) root and tuber plant after cassava in tropical countries [2] and the third (3rd) in sub-Saharan Africa after cassava and yam [3]. In Africa, Tanzania is the first producing country (3.47 million tonnes), followed by Nigeria (3.45 million tonnes), Uganda (2.59 million tonnes), Kenya (1.15 million tonnes), Madagascar (1.13 million tonnes) and Rwanda (1.08 million tonnes). Côte d'Ivoire has produced 47,914 tonnes in 2013 [4].

The sweet potato is often cultivated as a reserve for welding. This is what gives it special value in food security. Sweet potato is a subsistence crop in production areas [5]. It has many agronomic advantages, including a low input requirement. It provides good soil cover and favorable climates give high yields of up to 80 tonnes / hectare [6]. Sweet potato is also used as a raw material in canning, brewing, starch and starch. It is also used as fodder, especially for fish farming and porcine culture, in addition to being consumed as tuberous roots or green vegetables [6]. Its chemical composition and its modifications by cooking make it an energetic food, independently of artisanal or industrial transformations. In addition to this dominant energetic food use, it is necessary to underline its dietetic and medicinal interest in particular for its action against diabetes. Its consumption is known in China, beneficial to the kidney, spleen and stomach [6].

In Côte d'Ivoire, despite this importance, many factors limit the production of this crop. These are among others: the progressive loss of traditional varieties, the decline in soil fertility, the lack of varieties with high yield potential, pest pressure, the lack of availability of good seeds in good time and the low level of adoption of technologies developed by research. To solve these problems, it is initiated by the National Center for Agronomic Research (CNRA) in collaboration with Helen Keller International (HKI) a selection program for high-performance varieties. The selection of these varieties is made according to their 
vigor, their resistance to diseases and pests, their vitamin A content, their yield, their health, their ability to cook and their taste. This is what justifies our work, the general objective of which is to determine the yields and the dry matter rate of seven (7) varieties of sweet potato (Ipomoea batatas (L), Lam., 1793) in the Bouake region, Côte d'Ivoire.

\section{MATERIAL AND METHODS MATERIAL \\ Study Area}

Bouaké is located in the center of Côte d'Ivoire, about $350 \mathrm{~km}$ from Abidjan [7]. The city is on a flat relief, with a large constellation of 143 villages enumerated within a radius of 20 kilometers. The vegetation of the region is covered with a wooded savannah and crossed by the Kan river. This city is located at latitude $7^{\circ} 69 \mathrm{~N}$ and longitude $5^{\circ} 03 \mathrm{~W}$, covers an area of approximately $72 \mathrm{~km}^{2}$ [8]. It is influenced by a humid tropical climate, a high thermal amplitude $\left(22^{\circ} \mathrm{C}\right.$ in the morning to $35^{\circ} \mathrm{C}$ in the afternoon), constant sunshine and low humidity. There are also four seasons for the city of Bouaké [7]:

- Hot, dry and not rainy season (November to February);

- Hot, humid and rainy season (March to June);

- Cool, humid and not very rainy season (July to August);
- Cool, wet and rainy season (September and October).

\section{Vegetal Material}

The plant material used consists of seven (7) varieties of sweet potato to be evaluated, which are: Fadanga, Pourpre (T9-Purple), Covington, Tiébélé 2, CIP (CIP19906261), CIP4 (BF52XCIP4) and the variety Irène (Figure-1). The latter (Irène), already known in Côte d'Ivoire will be considered a witness compared to the other six. The seeds come from the production site of the company Agri Ivoire Environnement (AIE).

\section{METHODS \\ Experimental Apparatus}

The test took place over six (6) months, from August 2018 to January 2019. The experimental device (Figure-2) is a Fisher block comprising a single factor with three repetitions. The elementary plot, $5 \mathrm{~m}$ long and $3 \mathrm{~m}$ wide, is made up of 24 mounds. The distance between two elementary plots is $1.5 \mathrm{~m}$. The distance between two consecutive repetitions is $2 \mathrm{~m}$. Thus a repetition comprises seven elementary plots. The rehearsal was performed over a length of $44 \mathrm{~m}$ and a width of $3 \mathrm{~m}$. The experiment is carried out on an area of $572 \mathrm{~m}^{2}$. For this experiment, no fertilizer was used.

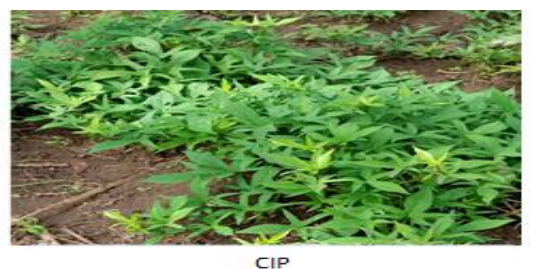

CIP
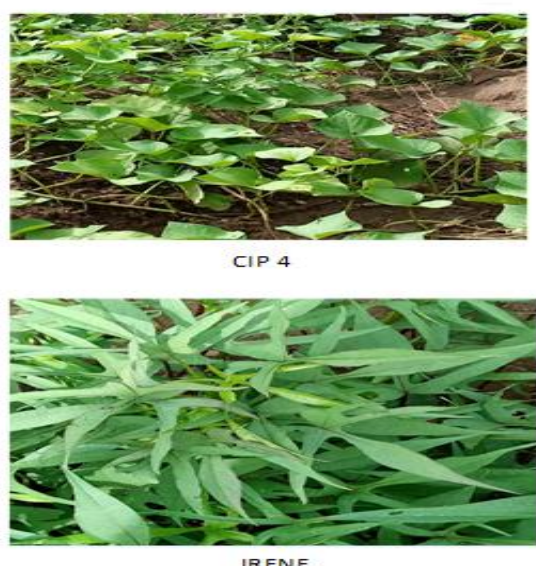

IRENE

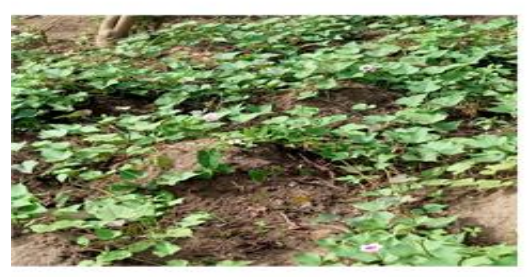

COVINGTON

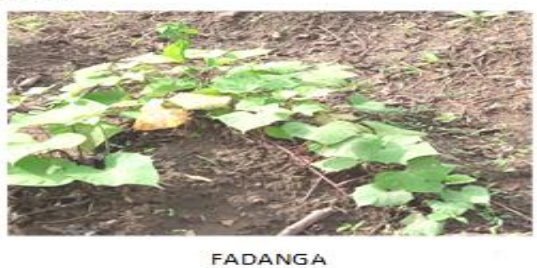

Fig-1: Photograph of the aerial parts of the different varieties of sweet potato used 


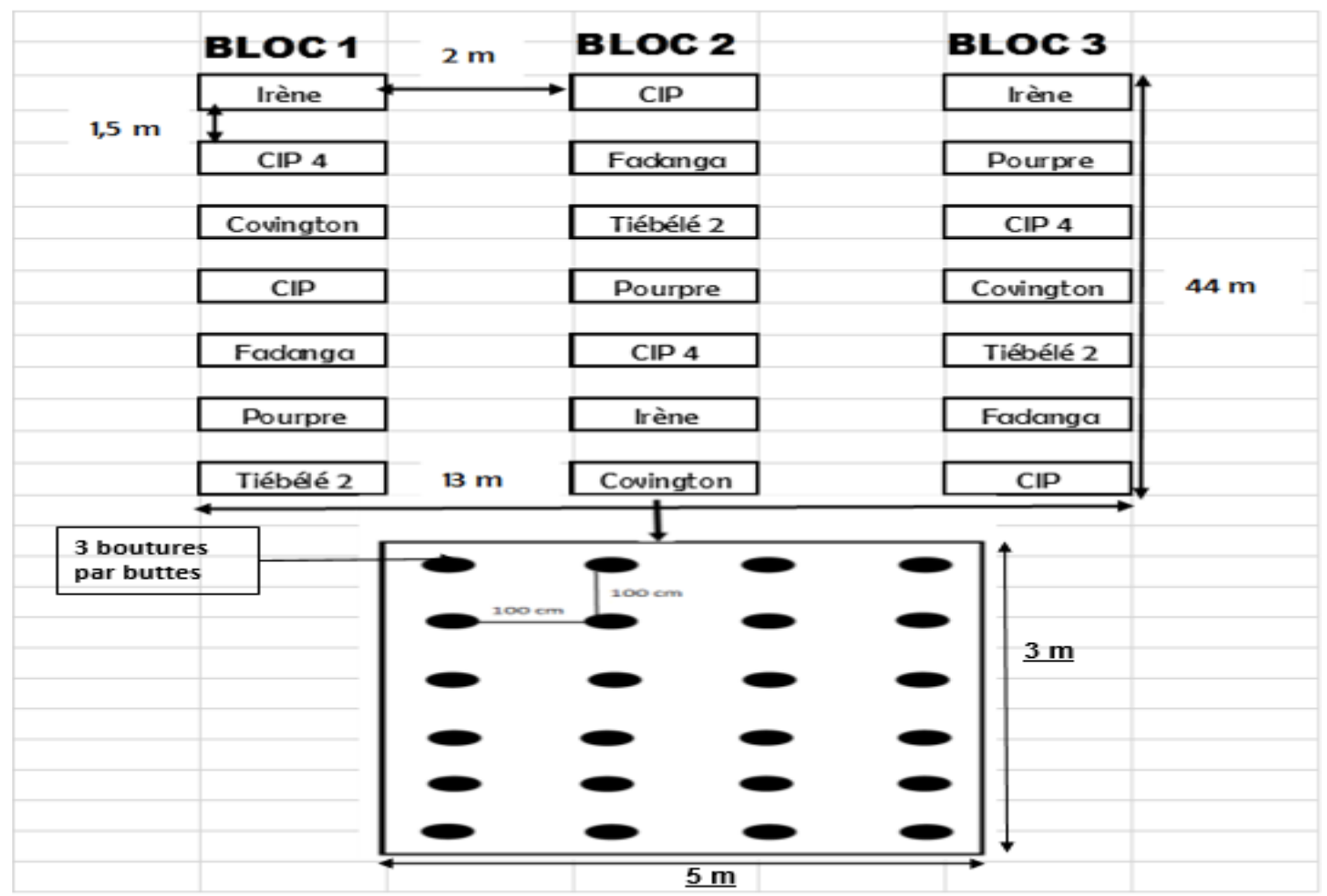

Fig-2: Experimental apparatus

\section{Cultivation}

The site was previously weeded. Then, the staking and plowing were carried out before the making of the $1 \mathrm{~m}^{2}$ mounds. Cuttings of three (3) to four (4) knots were cut at the Agri Ivoire Environnement cuttings production site and then planted. Only the ends of these plants were taken as cuttings because the latter harbor fewer eggs and weevil larvae and give more vigorous plants. These 15 to $30 \mathrm{~cm}$ long cuttings were stripped before being transplanted at the rate of three cuttings per hill. The cuttings were transplanted obliquely with 2 to 3 knots in the ground and 1 to 2 knots above the ground. Transplanting was done variety by variety and block after block.

\section{Field Maintenance}

The maintenance of the plot was done by manual weeding. It was done regularly when the need arose to clear the field of weeds.

\section{Collection of Data}

At harvest several agronomic parameters were determined. These are the size of the tuberous roots (number of small tuberous roots (NSR) and their weight (WPR), the number of large tuberous roots (NLR) and their weight (WLR) and finally the total number of tuberous roots (TNR) and their weight (WNR). The dry matter level (DML) was also evaluated. For each parameter, the value was obtained from the average of the 3 repetitions.
The size of the tuber roots and their weight was determined by separating and counting the small non-marketable roots (SNM) and large marketable roots (LMR). The roots considered to be of small size have a diameter less than or equal to $4 \mathrm{~cm}$ and those of large size have a diameter of more than $4 \mathrm{~cm}$;

The total number of tuberous roots (TNR) and their weight (TWR) was determined by counting the total number of tubers of each variety followed by their weighings.

The weight of the harvested roots was determined using a balance. The weights are expressed in $\mathrm{Kg}$. The values obtained were then expressed in tonnes per hectare.

\section{Dry Matter Rate}

After harvest, dry matter rates were determined by selecting tuberous roots at random by repetition and by variety for laboratory analysis. Samples were taken at three different levels: in the middle and close to the two ends of each chosen tuberous root. All these samples were then merged to obtain a representative sample per treatment. The pieces obtained were peeled and a fraction of $200 \mathrm{~g}$ was taken to give the fresh weight per sample. These $200 \mathrm{~g}$ fractions were then cut into small strips and then put in aluminum foil depending on the treatment. The aluminum foil containing these sweet potato strips was placed in the oven at $100^{\circ} \mathrm{C}$ for 24 hours. The dry and cooled samples were weighed to determine their dry weight. 
This made it possible to determine the dry matter content according to the following formula:

$$
\operatorname{DMR}(\%)=\frac{\text { DW }}{\text { FW }} X 100
$$

With:

DMR: Dry matter rate

DW: dry weight of sample (g)

FW: fresh weight of the sample $(\mathrm{g})$

\section{Data Processing}

The data collected was subjected to one-way variance analysis (ANOVA) with seven (7) variables using Statistica 7.1 software. This analysis was used to assess the effect of the variety on the measured parameters of sweetpotato. If there were significant differences at the $5 \%$ level, the Fisher test was used to classify the means into homogeneous groups.

\section{RESULTS}

Number and Total Weight of Tuberous Roots Produced

Figure- 3 shows the number and weight of the tuberous roots. In terms of total number of tuberous roots (TNR), the Covington variety (34,721 tuberous roots per hectare) recorded the highest value. It is followed by the CIP variety $(22,638$ tuberous roots per hectare). The Fadanga variety recorded the lowest value with 4,029 tuberous roots per hectare. The Irene variety produced more tuberous roots than the Tiébélé 2, CIP4 and Fadanga varieties. As for the total weight of tuberous roots (TWR) (Figure-4), the highest value (5.56 t / ha) is recorded with the Covington variety. It was followed by the CIP (4.44 t / ha) and Purple (3.22 t / ha) varieties. However, the lowest value $(1.11 \mathrm{t} / \mathrm{ha})$ was noted with the variety Table- 2 .

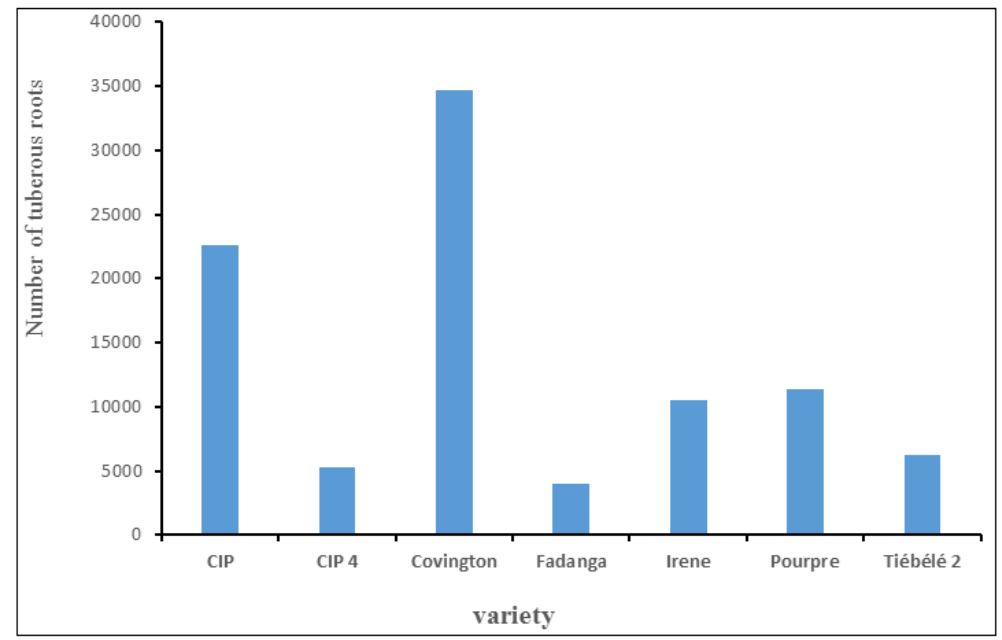

Fig-3: Total number of tuberous roots of different varieties of sweet potato

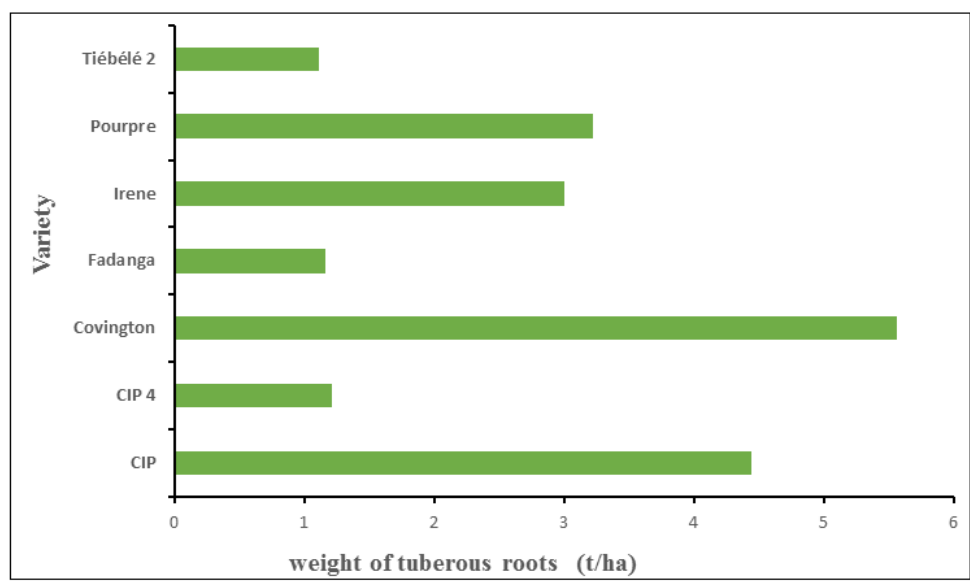

Fig-4: Total weight of tuberous roots of different varieties of sweet potato

\section{Size of the Tuberous Roots According to the Variety of Sweet Potato}

Table-1 shows the number and weight of marketable and non-marketable tuberous roots of the different varieties. A very highly significant difference $(\mathrm{p}<0.001)$ was observed between the varieties regarding the number of non-marketable tuberous roots. The Covington variety produced more non-marketable tuberous roots $(76.67 \pm 7)$. It is followed by the variety CIP (48.67 \pm 17.04$)$. The varieties Fadanga (14.67 \pm 1.53), Tiébélé $2(15 \pm 3)$, CIP 4 (18 \pm 6.08), Irene $(21.33 \pm 15.31)$ and Purple $(24.33 \pm 0,58)$ show no 
significant difference. However, the Fadanga variety produced the smallest number of non-marketable roots. Regarding the size of the tuberous roots, the largest roots were obtained by the Covington variety (5.67 \pm 2.08) while the Fadanga variety produced the smallest roots $(1 \pm 0.5)$. The Irène variety does not differ significantly from all varieties except Covington which has small tuberous roots compared to Irene roots $(\mathrm{p}<$ 0.001). As for the number and size of marketable roots, there is a significant difference between all the varieties. The Covington variety $(6.67 \pm 3.51$ and 2.67 $\pm 1.53)$ and the Tiébélé 2 variety $(0 \pm 0 ; 0 \pm 0)$ obtained the largest and smallest values respectively. The number and weight of Irene's roots does not differ significantly from that of the CIP, Covington and Purple varieties. In contrast, the varieties CIP4, Fadanga and Tiébélé 2 have weights of tuberous roots significantly different from that of Irène.

Table-1: Size of tuberous roots of different varieties of sweet potato

\begin{tabular}{|l|l|l|l|l|}
\hline Variety & NSR & WSR (t) & NLR & WLR (t) \\
\hline IRENE & $21.33 \pm 15.31^{\mathrm{c}}$ & $2.5 \pm 1,8^{\mathrm{a}, \mathrm{b}}$ & $4 \pm 2^{\mathrm{a}}$ & $2 \pm 1^{\mathrm{a}}$ \\
\hline CIP 4 & $18 \pm 6.08^{\mathrm{c}}$ & $1.5 \pm 0.5^{\mathrm{a}, \mathrm{b}}$ & $1.33 \pm 1.15^{\mathrm{b}}$ & $0.33 \pm 0.29^{\mathrm{b}}$ \\
\hline COVINGTON & $76.67 \pm 76.67^{\mathrm{a}}$ & $5.67 \pm 2.08^{\mathrm{c}}$ & $6.67 \pm 3.51^{\mathrm{a}}$ & $2.67 \pm 1.53^{\mathrm{a}}$ \\
\hline CIP & $48.67 \pm 17.04^{\mathrm{b}}$ & $4.17 \pm 0.76^{\mathrm{a}, \mathrm{b}, \mathrm{c}}$ & $5.67 \pm 2.89^{\mathrm{a}}$ & $2.5 \pm 1^{\mathrm{a}}$ \\
\hline FADANGA & $14.67 \pm 1.53^{\mathrm{c}}$ & $1 \pm 0.5^{\mathrm{a}}$ & $1.67 \pm 2.08^{\mathrm{b}}$ & $0.67 \pm 0.76^{\mathrm{b}}$ \\
\hline POURPRE & $24.33 \pm 0.58^{\mathrm{c}}$ & $3.170 .76^{\mathrm{a}, \mathrm{b}}$ & $3 \pm 3^{\mathrm{a}}$ & $1.67 \pm 1.53^{\mathrm{a}}$ \\
\hline TIEBELE 2 & $15 \pm 3^{\mathrm{c}}$ & $1.67 \pm 0.29^{\mathrm{a}, \mathrm{b}}$ & $0 \pm 0^{\mathrm{c}}$ & $0 \pm 0^{\mathrm{c}}$ \\
\hline p-value $(\boldsymbol{A N O \boldsymbol { N A } )}$ & 0.000021 & 0.002391 & 0.037938 & 0.031281 \\
\hline
\end{tabular}

Means with the same letters show no significant differences according to Fisher's ANOVA and LSD tests at the 5\% level. NSR: Number of Small Tuberous Roots; WSR: Weight of Small tuberous roots; NLR: Number of large tuberous roots; WLR: Weight of large tuberous roots.

\section{Dry Matter Content of Different Varieties of Sweet Potato}

Figure-5 shows the dry matter content of the different varieties of sweet potato. The dry matter content varied between $27.1 \%$ (Covington variety) and $38.7 \%$ (Purple variety). At the level of this parameter, the variety Irene recorded a higher value than that of the varieties CIP 4, Covington, CIP and Tiébélé 2 while the varieties Fadanga and Purple obtained higher values than the variety Irène.

Table-2: Dry matter content of different varieties of sweet potato

\begin{tabular}{|c|c|c|c|}
\hline Variety & FW (g) & DW (g) & DMR (\%) \\
\hline IRENE & \multirow{7}{*}{200} & 62.08 & 31.04 \\
\hline CIP 4 & & 60.74 & 30.37 \\
\hline COVINGTON & & 54.32 & 27.16 \\
\hline CIP & & 59.38 & 29.69 \\
\hline FADANGA & & 71.84 & 35.92 \\
\hline POURPRE & & 77.46 & 38.73 \\
\hline TIEBELE 2 & & 60.92 & 30.46 \\
\hline
\end{tabular}

\section{DISCUSSION}

The yields of tuberous roots (number, weight and shape) were all different according to the varieties. The number of tubers per plant varied depending on the variety. During the evaluation of all these performance parameters, the Covington, CIP and Pourpre varieties obtained higher values than those of the Irene variety. In all cases, the results obtained are far superior to those obtained in the 4 sweet potato varieties, namely Mugandé, Spk013, Kemb 10 and SPK004 cultivated in West Kenya by Ndolo et al., [9]. Similarly, in the varieties Yan Shu1 and White Delite cultivated in eastern Congo by Phemba et al., [10], the number of tubers per plant is almost identical to our results. These satisfactory results would be justified by the favorable climatic conditions in the Bouaké region in particular, the type of soil, the temperature of the environment and above all the rainfall. Djinet et al., [11] during their experiments in Chad and Burkina Faso also demonstrated that the values measured in terms of yields of sweet potato roots vary according to the varieties.

With regard to the number of marketable and non-marketable roots, it is noted that the Covington and CIP varieties which had the highest root weights produced more non-marketable roots. It is quite the opposite in the Fadanga variety which, with a low yield, obtained the highest number of marketable tuberous roots. These observations point out that in general, in terms of productivity, the Covington and CIP varieties had the highest yield than all the other varieties. In fact, they produced as many large tubers as small tubers, unlike the Fadanga variety which produced only a few 
large tubers. Rainfall was the basis for these observations. Indeed, our experiment took place over two climatic periods. A rainy period and another not very rainy. Certain tubers would therefore be influenced in their development by the lack of water. The lack of rain reported as a major difficulty in the production of sweet potato is consistent with what Doussoh et al., [12] also noted in the production of sweet potato in Benin. Janssens [13] also showed that sweet potato plants produced more reserve roots, which increased in weight when the air temperature was $20^{\circ} \mathrm{C}$.

The dry matter rates were different depending on the variety. It is between $27 \%$ and $39 \%$. The Covington, CIP, CIP 4 and Tiébélé 2 varieties achieved higher dry matter levels than Irene. On the other hand, the Purple and Fadanga varieties had dry matter rates lower than that of the control. This high dry matter content in these different varieties could be explained by the fact that their respective tubers have a relatively low humidity rate [14]. Our results are identical to those of Feruzi et al., [15] during the post-harvest evaluation of six sweetpotato genotypes selected in eastern Congo.

\section{CONCLUSION}

The purpose of this study was to assess the yields and dry matter content of seven (7) sweet potato varieties in the Bouaké region, Côte d'Ivoire. Based on the yield results, Covington, CIP were the best. The Fadanga variety had the lowest yield. Regarding the dry matter rate, the Purple and Fadanga varieties had the highest rate. No single variety has combined all the performance in terms of yield and dry matter. However, the CIP and Covington varieties in view of their yield above the control and their dry matter content close to Irene could very well adapt.

\section{ACKNOWLEDGEMENT}

This work was supported by the National Center for Agricultural Research, the Helen Keller International Foundation (HKI) and Agri Ivoire Environnement (AIE).

\section{REFERENCES}

1. Hironori M, Ogasawara F, Sato K, Higo $\mathrm{H}$, Minobe Y. Isolation of a regulatory gene of anthocyanin biosynthesis in tuberous roots of purple-fleshed sweet potato. Plant Physiology. 2007; 143: 1252-1268.

2. FAOSTAT.

http://faostat.fao.org/site/567/default.aspx. (http:/www.ars-grin.gov/). 2006.

3. Karyeija RF, Gibson RWJ, Valkonen PT. The significance of sweet potato feathery mottle virus in subsistence sweet potato production in Africa. Plant Disease. 1998; 82: 4-15.

4. FAOSTAT.

http://faostat3.fao.org/download/Q/QC/E. consulté le 23 mai 2018.
5. CTA. La patate douce, In : Asian végétale reseach et développement centre, acte du premier symposium international, CTA VILLAREAL R., GIGGS T.D Wageningen, 2007; 514.

6. CTA. Rapport annuel du CTA 2007. CTA, Wageningen, Pays-Bas. 2008;513.

7. Yesso P, Kone D, Meyer C. Reprise post-partum et cyclicité des vaches trypanotolérantes en fonction de la variation saisonnière en région centre Côte d'Ivoire In : IAEA sur l'Amélioration de la Productivité du Bétail Indigène Africain en Utilisant les Méthodes Radio-immunologiques et Apparentées. Réunion de Coordination FAO. 3, Bouaké, IDESSA. 1991; 22.

8. Allouko JR. Etude du prégrossissement d'Oreochromis niloticus en étang de rizipisciculture. Mémoire de fin d'étude de Diplôme d'Agronmie Approfondie, Institut National Félix Houphouët Boigny, Yamoussoukro, Côte d'Ivoire. 2011: 50.

9. Ndolo PJ, Mcharo T, Carey EE, Gichuki ST, Ndinya C, Maling'a J. Participatory on-farm selection of sweet potato varieties in western Kenya. African Crop Science Journal. 2001 Mar;9(1):41-8.

10. Phemba P, Mutombo T, Lutaladio NB, Carey EE. Performance et stabilité de rendement des génotypes de patate douce dans divers environnements à l'est du Congo. African Crop Science Journal. 1998;6(2):109-118.

11. Djinet AI, Nana R, Tamini Z, Badiel B. Etude comparée des paramètres agromorphologiques de dix (10) variétés de patate douce (Ipomoea batatas (L.) Lam cultivées au champ dans deux (2) conditions climatiques au Tchad et au Burkina Faso. International Journal of Biological and Chemical Sciences. 2015; 9(3):1243-1251.

12. Doussoh AM, Dangou JS, Houedjissin SS, Assogba AK, Ahanhanzo C. Analyse des connaissances endogènes et des déterminants de la production de la patate douce [Ipomoea batatas (L.)], une culture à haute valeur socioculturelle et économique au Bénin. International Journal of Biological and Chemical Sciences. 2016;10(6):2596-616.

13. Janssens MJJ. Sweet potatoes (Ipomoea batatas L) Lam: In Crop Production in the tropical Romain $\mathrm{H}$ Raemaekersed. 2001; 205-220.

14. Djinet AI, Nana R, Nguinambaye MM, Badiel B, Konaté B, Nanema L, Tamini Z. Etude du comportement de dix (10) variétés de patate douce cultivées à Bongor en saison sèche. International Journal of Innovation and Applied Studies. 2016; 17(4): 1384-1390.

15. Feruzi M, Phemba P, Ngongo M, Hagenimana V, Lutaladio NB. Évaluation post récolte de six génotypes de patate douce sélectionnés à l'Est du Congo. African Crop Science Journal. 2001; 9(1): 33-39. 